\title{
Pengaruh Locus Of Control, Financial Knowledge, Income Terhadap Financial Management Behavior
}

\section{SERLY NOVIANTI}

\author{
Universitas Riau \\ Jln. H.R Subrantas KM 10 Panam 28293 \\ E-mail : erlynovianti.stie@gmail.com
}

\begin{abstract}
The purpose of this study was to analyze the effect of Locus of Control, Financial Knowledge, Income of the Financial Management Behavior (Empirical Study On Government Agencies Bappeda Riau Province and Bappeda City / Regency). This study uses multiple linear regression analysis. To determine the effect of independent variables on the dependent variable partially used t test, while to know the effect of independent variables on the dependent variable simultaneously used $\mathrm{F}$ test population in the study were all employees of the status of Civil Servants On Government Agencies Bappeda Riau Province and Bappeda City / Regency which amounted to 195 people. While the number of samples using the formula Slovin and obtained a sample of 131 people. The data were obtained using a questionnaire, were analyzed with regression at $\alpha=0: 05$. The results showed that the statistically variable Locus of Control, Financial Knowledge, Income simultaneously significant effect on the Financial Management Behavior $(p<0.05)$ with the percentage of the effect of locus of control at $-11.1 \%$, amounting to 52.7 Effect of financial knowledge $\%$ and income amounted to $-95.4 \%$. For the partial research results indicate variable Locus of Control has no effect on the Financial Management Behavior, while Financial Knowledge and significant effect on the Income Financial Management Behavior. It is suggested to Government Agencies Bappeda Riau Province and Bappeda City / Regency to: 1) Increase the Locus of Control by using a system of reward and punishment to employees who perform or make mistakes, 2) Improve Financial Knowledge clerks in a manner often provide training to bring in resource persons who competent 3) Prepare Income feeding patterns based on employee performance.
\end{abstract}

Keywords: Locus of Control, Financial Knowledge, Income and Financial Management Behavior

Perencanaan pembangunan daerah merupakan pekerjaan yang sangat penting, karena dengan perencanaan kita bisa membaca dan merencana mau dibawa kemana daerah kedepannya, dengan tetap memperhatikan potensi dan sumber daya yang dimiliki. UU Nomor 25 Tahun 2004 tentang Sistem Perencanaan Pembangunan Nasional mendefenisikan perencanaan sebagai suatu proses untuk menentukan tindakan masa depan yang tepat, melalui urutan pilihan, dengan memperhitungkan sumber daya yang tersedia.

Menurut jurnal Naila \& Iramani (2013), Financial Management Behavior adalah kemampuan seseorang dalam mengatur (perencanaan, penganggaran, pemeriksaan, pengelolaan, pengendalian, pencarian dan penyimpanan) dana keuangan. Munculnya Financial Management Behavior, merupakan dampak dari besarnya hasrat seseorang untuk memenuhi kebutuhan hidupnya sesuai dengan tingkat pendapatan yang diperoleh. Financial Management Behavior berhubungan dengan tanggung jawab keuangan seseorang mengenai cara pengelolaan keuangan.

Berdasarkan penelitian terdahulu terdapat tiga variabel lain yang mempengaruhi perilaku keuangan (financial management behavior), yaitu locus of control, financial knowledge dan income.

Dari latar belakang masalah penelitian diatas masalah pokok dalam tesis ini adalah Locus of Control, Finansial Knowledge, Income terhadap Financial 
Management Behavior. Artinya, penelitian ini khusus memuat materi Financial Management Behavior. Rumusan permasalahan yang akan dibahas dalam tesis ini adalah: apakah Locus of Control dapat mempengaruhi Financial Management Behavior pada instansi pemerintah Bappeda Provinsi Riau dan Bappeda Kota/Kabupaten?; apakah Financial Knowledge dapat mempengaruhi Financial Management Behavior pada instansi pemerintah Bappeda Provinsi Riau dan Bappeda Kota/Kabupaten?; apakah Income dapat mempengaruhi Financial Management Behavior pada instansi pemerintah Bappeda Provinsi Riau dan Bappeda Kota/Kabupaten? Apakah Locus of Control, Financial Knowledge, Income secara bersama-sama (simultan) berpengaruh terhadap Financial Management Behavior pada instansi pemerintah Bappeda Provinsi Riau dan Bappeda Kota/Kabupaten?

Financial Management Behavior adalah kemampuan seseorang dalam mengatur (perencanaan, penganggaran, pemeriksaan, pengelolaan, pengendalian, pencarian dan penyimpanan) dana keuangan sehari-hari. Menurut Bringham \& Houston (2010) yaitu kegagalan etika dalam prilaku manajemen keuangan menimbulkan sejumlah kebangkrutan.

Menurut Robbin (2001) locus of control mengandung arti seberapa jauh individu yakin bahwa mereka menguasai nasib mereka sendiri. Menurut Pervin (2005) locus of control merupakan konsep dari teori social learning yang telah dikembangkan oleh JB. Rotter yang menyangkut kepribadian dan mewakili harapan umum mengenai faktor-faktor yang menentukan keberhasilan, hadiah, dan hukuman pada kehidupan seseorang.

Menurut Duffy \& Atwarer (2005) mengemukakan definisi Locus of control adalah sumber keyakinan yang dimiliki oleh individu dalam mengendalikan peristiwa yang terjadi baik itu dari diri sendiri ataupun dari luar dirinya. Locus of control pertama kali dikemukakan oleh Rotter (1966), dimana teori ini merupakan perkembangan dari Teori
,Belajar Sosial. Rotter menyatakan salah satu faktor individual yang mengendalikan peristiwa kehidupan seseorang adalah locus of control yang ada pada dirinya. Locus of control juga memberikan gambaran pada keyakinan seseorang mengenai sumber penentu perilakunya. Ditambahkan pula bahwa locus of control adalah suatu cara dimana individu memiliki tanggung jawab terhadap kegiatan yang terjadi di dalam kontrol atau di luar kontrol dirinya.

Kecerdasan finansial dalam kehidupan bermasyarakat lebih akrab dikenal dengan istilah kemelekan finansial tak jarang pula kedua istilah tersebut dipertukarkan satu sama lain. Namun secara teoritis, kedua istilah tersebut memang mempunyai arti yang hampir sama satu sama lain. Seseorang yang melek secara finansial belum tentu memiliki kecerdasan finansial yang tinggi, sebagai contoh orang yang bekerja di bidang akuntan, mereka mungkin tahu detil tentang aset dan liabilitas perusahaan, tapi seringkali mereka tidak mampu menciptakan dan mengolah kekayaannya sendiri.

Dalam praktiknya fungsi akuntansi adalah melakukan pengukuran kinerja atau prestasi management perusahaan. Produk akuntansi yaitu laporan keuangan diharapkan dapat memberikan tolak ukur secara jelas terhadap prestasi perusahaan. Banyak faktor dalam laporan keuangan yang dapat menjadi tolak ukur, salah satu faktor yang digunakan adalah pengukuran income atau laba. Laba merupakan elemen penting yang menjadi perhatian para pemakai laporan keuangan karena diharapkan laba cukup besar untuk menunjukkan kinerja perusahaan dinilai baik secara keseluruhan.

Dari penjelasan kerangka pemikiran di atas, maka model penelitian dalam penelitian ini diilustrasikan seperti yang ditunjukkan pada gambar dibawah ini. Penilitian ini terdiri dari 4 variabel. Yaitu pengaruh Locus of Control, Finansial Knowledge, Income terhadap Finansial Manajemen Behavior. Maka digunakan model penelitian sebagai berikut : 


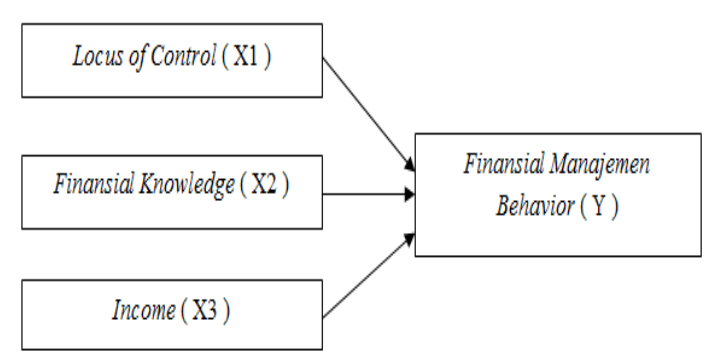

\section{METODE}

Pengujian hipotesis dilakukan dengan menggunakan model analisis regresi berganda bertujuan untuk memprediksi berapa besar kekuatan pengaruh variabel independen terhadap variabel dependen.

$Y=\beta 0+\beta_{1} X_{1}+\beta_{2} X+\beta_{3} X_{3}+e$

$\mathrm{Y}=$ Financial Management Behaviour $\beta_{0}=$ intersep

$\beta 1, \beta 2, \beta 3=$ koefisien regresi

$\mathrm{X}_{1}=$ Locus of Control

$\mathrm{X}_{2}=$ Financial Knowledge

$\mathrm{X} 3=$ Income

\section{$\mathrm{E}=$ Disturbance error}

Setelah hasil analisis regresi memenuhi asumsi klasik yang telah ditetapkan, maka hasil analisis regresi dapat digunakan untuk menguji hipotesis. Pengujian hipotesis penelitian ini dilakukan dengan menggunakan uji $\mathrm{F}$ dan uji t.

Penelitian ini menggunakan metode deskriptif analitis dimana penelitian mengambil sampel dari populasi dan menggunakan kuisioner sebagai alat pengumpulan data. Setelah data diperoleh kemudian hasilnya disajikan secara deskriptif dan pada akhir penelitian akan dianalisis untuk menguji hipotesis yang diajukan pada awal penelitian ini.

Populasi dalam penelitian ini seluruh pegawai tetap Bappeda Provinsi Riau dan Bappeda Kota/Kabupaten yang berjumlah 195 orang. Sedangkan sampelnya adalah sebagian dari anggota populasi tersebut. Pengambilan sampel dilakukan secara acak. Kriteria yang digunakan dalam pengambilan sampel adalah: (1) pegawai tetap, dan (2) tidak memiliki jabatan struktural. Dalam sampel dianbil secara acak.

Adapun untuk menentukan ukuran sample menggunakan rumus Slovin menurut Riduwan dan Akdon (2006), sebagai berikut :

$$
\begin{aligned}
\mathrm{n}= & \frac{N}{\left(N \cdot d^{2}\right)+1} \\
= & \frac{195}{\left(195 \times 5 \% \%^{2}\right)+1}=131 \text { orang } \\
& \text { dimana : } \\
& \mathrm{n} \quad: \text { Jumlah sample } \\
& \mathrm{N} \quad: \text { Jumlah populasi } \\
& \mathrm{d} \quad: \text { Persen kesalahan yang ditolerir }
\end{aligned}
$$

Prosedur pengambilan data dalam penelitian ini dilakukan dengan menggunakan kuesioner. Teknik kuesioner merupakan teknik pengumpulan data yang dilakukan dengan cara memberi seperangkat pertanyaan atau pernyataan tertulis kepada responden untuk dijawabnya menurut Sugiyono (2011).

Penyekoran variabel dalam penelitian ini dilakukan dengan menjumlah skor dari seluruh skor item pertanyaan yang terdapat

\begin{tabular}{|c|c|c|}
\hline Variabel & Indikator & Skala \\
\hline \multirow[t]{4}{*}{$\begin{array}{l}\text { Locus of } \\
\text { Control }\end{array}$} & $\begin{array}{l}\text { Seberapa sering } \\
\text { anda merasa pada } \\
\text { bidang berikut ini : }\end{array}$ & \multirow[t]{4}{*}{ Likert } \\
\hline & $\begin{array}{l}\text { a.Benar-benar tidak } \\
\text { ada sama sekali cara } \\
\text { untuk saya } \\
\text { memecahkan } \\
\text { masalah saya }\end{array}$ & \\
\hline & $\begin{array}{l}\text { b.Saya } \\
\text { didorong(dipengaru } \\
\text { hi) kehidupan } \\
\text { disekitar saya }\end{array}$ & \\
\hline & $\begin{array}{l}\text { c.Hanya sedikit } \\
\text { yang bisa saya } \\
\text { lakukan untuk } \\
\text { mengubah hal-hal }\end{array}$ & \\
\hline
\end{tabular}
dalam variabel yang bersangkutan. Penyekoran terhadap item pertanyaan dilakukan dengan menggunakan skala Likert 5 point menurut Sekaran (2003).

\section{Tabel 1. Definisi Operasional Variabel}




\begin{tabular}{|c|c|c|}
\hline Variabel & Indikator & Skala \\
\hline & $\begin{array}{l}\text { penting dalam hidup } \\
\text { saya }\end{array}$ & \\
\hline & $\begin{array}{l}\text { d.Saya bisa } \\
\text { melakukan apapun } \\
\text { yang sudah ada } \\
\text { dalam pikiran saya }\end{array}$ & \\
\hline & $\begin{array}{l}\text { e.Apa yang terjadi } \\
\text { dengan saya dimasa } \\
\text { depan tergantung } \\
\text { pada saya }\end{array}$ & \\
\hline & $\begin{array}{l}\text { f.Tidak berdaya } \\
\text { dalam menghadapi } \\
\text { masalah kehidupan }\end{array}$ & \\
\hline & $\begin{array}{l}\text { g. Saya memiliki } \\
\text { sedikit kontrol atas } \\
\text { hal-hal yang } \\
\text { terjadipada saya }\end{array}$ & \\
\hline \multirow[t]{6}{*}{$\begin{array}{l}\text { Financial } \\
\text { Knowledg } \\
e\end{array}$} & $\begin{array}{l}\text { Berapa banyak hal } \\
\text { yang anda tahu } \\
\text { tentang hal berikut: }\end{array}$ & \multirow[t]{6}{*}{ Likert } \\
\hline & $\begin{array}{l}\text { a.Istilah suku bunga, } \\
\text { beban keuangan dan } \\
\text { kredit }\end{array}$ & \\
\hline & $\begin{array}{l}\text { b. Credit Rating dan } \\
\text { Credit Files }\end{array}$ & \\
\hline & $\begin{array}{l}\text { c.Mengelola } \\
\text { keuangan }\end{array}$ & \\
\hline & $\begin{array}{l}\text { d.Menginvestasikan } \\
\text { uang }\end{array}$ & \\
\hline & $\begin{array}{l}\text { e.Apa yang ada di } \\
\text { laporan kredit anda }\end{array}$ & \\
\hline Income & $\begin{array}{l}\text { Berapa total } \\
\text { pendapatan anda } \\
\text { (dan gabungkan } \\
\text { pasangan } \\
\text { anda)sebelum pajak } \\
\text { penghasilan?silahka } \\
\text { n } \\
\text { mempertimbangkan } \\
\text { pendapatan dari } \\
\text { semua sumber, } \\
\text { termasuk kerja, } \\
\text { tunjangan, } \\
\text { tunjangan anak, } \\
\text { pendapatan sewa, } \\
\text { pendapatan investasi } \\
\text { dan setiap uang } \\
\text { lainnya yang } \\
\text { mungkin anda }\end{array}$ & $\begin{array}{l}\text { Kategor } \\
\mathrm{i}\end{array}$ \\
\hline
\end{tabular}

\begin{tabular}{|c|c|c|}
\hline Variabel & Indikator & Skala \\
\hline & $\begin{array}{l}\text { terima ( tandai satu } \\
\text { jawaban saja ): }\end{array}$ & \\
\hline & Di bawah 1 juta & \\
\hline & 1 juta -3 juta & \\
\hline & 3 juta -5 juta & \\
\hline & Di atas 5 juta & \\
\hline \multirow[t]{6}{*}{$\begin{array}{l}\text { Financial } \\
\text { Manajeme } \\
n \\
\text { Behavior }\end{array}$} & $\begin{array}{l}\text { Bagaimana } \\
\text { tingkatan diri anda } \\
\text { pada bidang berikut } \\
\text { ini : }\end{array}$ & \multirow[t]{6}{*}{ Likert } \\
\hline & $\begin{array}{l}\text { a.Mengontrol } \\
\text { pengeluaran }\end{array}$ & \\
\hline & $\begin{array}{l}\text { b.Membayar tagihan } \\
\text { saya tepat waktu }\end{array}$ & \\
\hline & $\begin{array}{l}\text { c.Membuat } \\
\text { perencanaan untuk } \\
\text { keuangan saya } \\
\text { dimasa depan }\end{array}$ & \\
\hline & $\begin{array}{l}\text { d.Menyediakan } \\
\text { untuk diri sendiri } \\
\text { dan keluarga saya }\end{array}$ & \\
\hline & e.Menyimpan & \\
\hline
\end{tabular}

Sumber : Ida dan Shintia (2010)

Metode analisis data dalam penelitian ini digunakan metode regresi linier berganda dimana hasil dari regresi linier berganda akan dapat digunakan sebagai alat prediksi yang baik dan tidak bias apabila memenuhi beberapa asumsi. Asumsi tersebut adalah normalitas, mulitikolinieritas dan heterokedastisitas

Tabel 2. Penentuan Kategori Skor Berdasarkan Kategori Jawaban Responden

\begin{tabular}{|c|c|c|}
\hline No & $\begin{array}{c}\text { Skala Kategori } \\
\text { Jawaban }\end{array}$ & Kategori \\
\hline 1. & $1,00-1,79$ & Sangat \\
2. & $1,80-2,59$ & rendah \\
3. & $2,60-3,39$ & Rendah \\
4. & $3,40-4,19$ & Sedang \\
5. & $4,20-5,00$ & Tinggi \\
& & Sangat Tinggi \\
\hline
\end{tabular}

Sumber (Sugiyono,2007)

Untuk menguji kualitas data yang diperoleh dari penerapan instrumen, maka diperlukan uji validitas, dan uji reliabilitas dengan penjelasan sebagai berikut: 
1. Uji Validitas

Menurut Ghozali (2006) uji validitas dilakukan dengan uji korelasi Pearson Moment antara masing-masing skor indikator dengan total skor konstruk. Suatu butir pertanyaan dikatakan valid jika nilai korelasi item butir dengan skor total signifikan pada tingkat signifikansi 0,01 dan 0,02.

\section{Uji Reliabilitas}

Kriteria yang digunakan dalam uji ini adalah One Shot, artinya satu kali pengukuran saja dan kemudian hasilnya dibandingkan dengan pertanyaan lainnya atau dengan kata lain mengukur korelasi antar jawaban pertanyaan. Statistical Product and Service Solution (SPSS) memberikan fasilitas untuk mengukur reliabilitas dengan uji statistik Cronbach Alpha $(\alpha)$. Jika nilai koefisien alpha lebih besar dari 0,60 maka disimpulkan bahwa intrumen penelitian tersebut handal atau reliabel menurut Ghozali (2006).

\section{HASIL}

Uji Validitas Variabel Locus of Control $\left(\mathbf{X}_{1}\right)$

Tabel 3: Hasil Uji Validitas Variabel Locus of Control $\left(\mathrm{X}_{1}\right)$

\begin{tabular}{|c|c|c|c|}
\hline Item Pernyataan & $\mathbf{r}_{\text {hitung }}$ & $\mathbf{r}_{\text {tabel }}$ & Hasil Uji \\
\hline 1 & 0,305 & 0,172 & Valid \\
\hline 2 & 0,208 & 0,172 & Valid \\
\hline 3 & 0,459 & 0,172 & Valid \\
\hline 4 & 0,279 & 0,172 & Valid \\
\hline 5 & 0,112 & 0,172 & Tidak Valid \\
\hline 6 & 0,605 & 0,172 & Valid \\
\hline 7 & 0,315 & 0,172 & Valid \\
\hline
\end{tabular}

Sumber: Hasil Pengolahan SPSS, 2013

Berdasarkan tabel di atas, maka kuesioner tentang Locus of Control yang terdiri dari 7 item pernyataan. 6 pernyataan dinyatakan valid dan 1 pernyataan tidak valid yaitu no. 5. Dikarenakan hasil $r_{\text {hitung }}$ $\mathrm{r}_{\text {tabel }}$ yaitu $0,112<0,172$ sehingga untuk analisis selanjutnya pernyataan tersebut tidak disertakan.

\section{Uji Validitas Variabel Financial Knowledge $\left(\mathrm{X}_{2}\right)$}

\section{Tabel 4. Hasil Uji Validitas Variabel Financial Knowledge}

\begin{tabular}{|c|c|c|c|}
\hline Item Pernyataan & $\mathbf{r}_{\text {hitung }}$ & $\mathbf{r}_{\text {tabel }}$ & Keterangan \\
\hline 1 & 0,703 & 0,172 & Valid \\
\hline 2 & 0,468 & 0,172 & Valid \\
\hline 3 & 0,600 & 0,172 & Valid \\
\hline 4 & 0,670 & 0,172 & Valid \\
\hline 5 & 0,663 & 0,172 & Valid \\
\hline
\end{tabular}

Sumber: Hasil Pengolahan SPSS, 2013

Berdasarkan tabel di atas, maka kuesioner tentang Financial Knowledge yang terdiri dari 5 item pernyataan ini mengindikasikan bahwa pilihan jawaban dari responden dinyatakan valid menurut Widarjono (2005). Artinya, bahwa keseluruhan pernyataan yang diberikan kepada responden sudah valid dan dapat digunakan untuk mengukur variabel yang diteliti.

\section{Uji Validitas Variabel Income $\left(\mathrm{X}_{3}\right)$}

Tabel 5. Hasil Uji Validitas Variabel Income $\left(\mathrm{X}_{3}\right)$

\begin{tabular}{|c|c|c|c|}
\hline Item Pernyataan & $\mathbf{r}_{\text {hitung }}$ & $\mathbf{r}_{\text {tabel }}$ & Keterangan \\
\hline 1 & 0,831 & 0,172 & Valid \\
\hline
\end{tabular}

Sumber: Hasil Pengolahan SPSS, 2013

Berdasarkan tabel di atas, maka kuesioner tentang Income dinyatakan valid, karena lebih besar dari $\mathrm{r}^{\text {tabel }}$, hal ini mengindikasikan bahwa pilihan jawaban dari responden dinyatakan valid dan dapat digunakan untuk mengukur variabel yang akan diteliti menurut Widarjono (2005). 
Uji Validitas Financial Management Behavior $\left(\mathbf{Y}_{1}\right)$

Tabel 6. Hasil Uji Validitas Variabel Financial Management Behavior $\left(\mathbf{Y}_{1}\right)$

\begin{tabular}{|c|c|c|c|}
\hline Item Pernyataan & $\mathbf{r}_{\text {hitung }}$ & $\mathbf{R}_{\text {tabel }}$ & Keterangan \\
\hline 1 & 0,699 & 0,172 & Valid \\
\hline 2 & 0,405 & 0,172 & Valid \\
\hline 3 & 0,728 & 0,172 & Valid \\
\hline 4 & 0,550 & 0,172 & Valid \\
\hline 5 & 0,696 & 0,172 & Valid \\
\hline
\end{tabular}

Sumber: Hasil Pengolahan SPSS, 2013

Berdasarkan tabel di atas, maka kuesioner tentang Financial Management Behavior yang terdiri dari 5 item pernyataan seluruhnya dinyatakan valid, masing-masing koefisien korelasi yang dimiliki tiap butirnya lebih besar dari 0,172, hal ini mengindikasikan bahwa seluruh pilihan jawaban dari responden dinyatakan valid menurut Widarjono (2005). Artinya, bahwa keseluruhan pernyataan yang diberikan kepada responden sudah cukup tepat untuk mengukur Financial Management Behavior.

\section{Pengujian Reliabilitas Instrumen}

\section{Tabel 7. Hasil Uji Reliabilitas}

Keseluruhan Variabel

\begin{tabular}{|l|c|c|c|}
\hline \multicolumn{1}{|c|}{ Variabel } & $\begin{array}{c}\text { Pearson } \\
\text { correlation }\end{array}$ & $\mathbf{r}_{\text {kritis }}$ & $\begin{array}{c}\text { Hasil } \\
\text { Uji }\end{array}$ \\
\hline $\begin{array}{l}\text { Locus of control } \\
\left(X_{1}\right)\end{array}$ & 0,657 & 0,600 & Reliabel \\
\hline $\begin{array}{l}\text { Financial } \\
\text { knowledge }\left(X_{2}\right)\end{array}$ & 0,777 & 0,600 & Reliabel \\
\hline income $\left(X_{3}\right)$ & 0,912 & 0,600 & Reliabel \\
\hline $\begin{array}{l}\text { Financial } \\
\text { management } \\
\text { behavior }\left(Y_{1}\right)\end{array}$ & 0,600 & Reliabel \\
\hline
\end{tabular}

Sumber: Hasil Pengolahan SPSS, 2013

Dari pengujian reliabilitas ini dapat diketahui bahwa locus of control, financial knowledge, income dan financial management behavior merupakan variabel yang seluruhnya dinyatakan reliabel atau memenuhi persyaratan, karena nilai korelasi masing-masing variabel melebihi angka 0,6.
Sehingga dapat digunakan dalam pengujian hipotesis.

\section{Pengujian Asumsi Klasik}

Dalam analisis ini perlu dilihat terlebih dahulu apakah data tersebut bisa dilakukan pengujian model regresi. Pengujian asumsi klasik dilakukan untuk menentukan model regresi dapat diterima secara ekonometrik

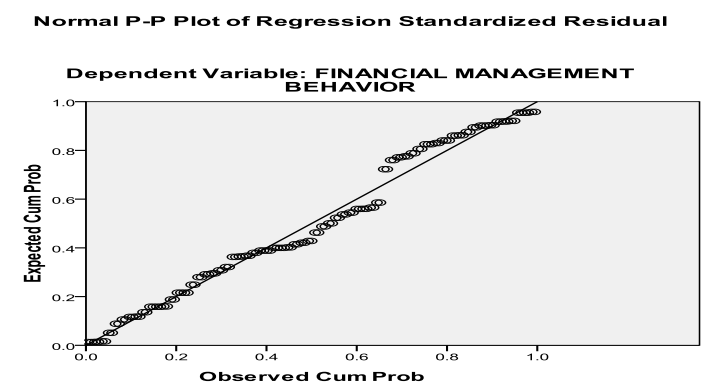

Gambar 1

\section{Normal Probability Plot}

Dari grafik output SPSS diatas terlihat bahwa titik-titik menyebar disekitar garis diagonal, serta penyebarannya mengikuti arah garis diagonal.

\section{Tabel 8 Uji Multikolinearitas}

\begin{tabular}{|c|l|l|l|l|}
\hline No & Variabel & $\begin{array}{l}\text { Tolera } \\
\text { nce } \\
\text { Value }\end{array}$ & VIF & Kesimpulan \\
\hline 1 & $\begin{array}{l}\text { Locus of } \\
\text { Control }\end{array}$ & 0,958 & $\begin{array}{l}1,04 \\
4\end{array}$ & $\begin{array}{l}\text { Bebas } \\
\text { multikoline } \\
\text { ritas }\end{array}$ \\
\hline 2 & $\begin{array}{l}\text { Financi } \\
\text { al } \\
\text { Knowle } \\
\text { dge }\end{array}$ & 0,976 & 1,02 & $\begin{array}{l}\text { Bebas } \\
\text { multikoline } \\
\text { ritas }\end{array}$ \\
\hline 3 & Income & 0,937 & 1,06 & $\begin{array}{l}\text { Bebas } \\
\text { multikoline } \\
\text { ritas }\end{array}$ \\
\hline
\end{tabular}

Sumber : data olahan

Dari hasil pengujian dapat dilihat bahwa tidak ada multikolinearitas pada variabel yang diukur, atau dengan kata lain konsekwensi praktis yang timbul sebagai akibat adanya multikolinearitas berupa 
kesalahan standar penaksir semakin besar dan probabilitas untuk menerima hipotesis yang salah dapat dihindari

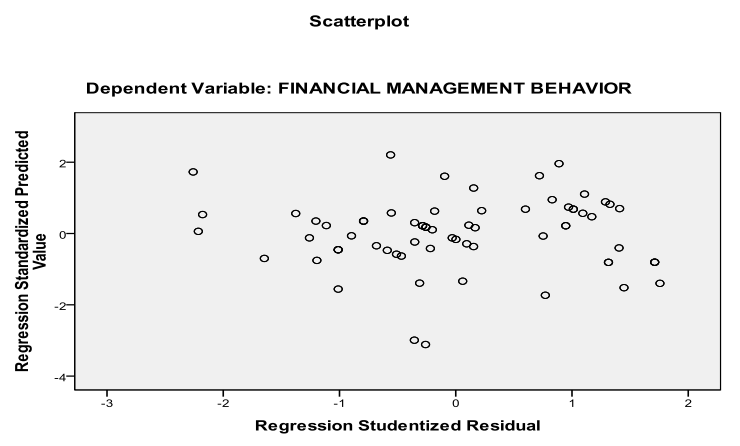

Gambar 2

Uji Heteroskedastisitas

\section{Uji Hipotesis}

Hasil pengujian Regresi melalui software SPSS 17 diperoleh hasil sebagai 1 berikut :

\section{Tabel 9 Hasil Uji Regresi}

\begin{tabular}{|c|c|c|c|c|c|}
\hline \multirow[b]{2}{*}{ Model } & \multicolumn{2}{|c|}{$\begin{array}{l}\text { Unstandardized } \\
\text { Coefficients }\end{array}$} & \multirow{2}{*}{$\begin{array}{c}\text { Standardized } \\
\text { Coefficients } \\
\text { Beta }\end{array}$} & \multirow[b]{2}{*}{$\mathrm{T}$} & \multirow[b]{2}{*}{ Sig. } \\
\hline & B & $\begin{array}{l}\text { Std. } \\
\text { Error }\end{array}$ & & & \\
\hline 1 (Constant) & 14,154 & 1,932 & & 7,327 &, 000 \\
\hline $\begin{array}{l}\text { Locus } \\
\text { control }\end{array}$ &,- 111 &, 072 &,- 112 & 1,539 &, 126 \\
\hline $\begin{array}{l}\text { Financial } \\
\text { knowledge }\end{array}$ &, 527 & ,066 &, 574 & 7,986 & ,000 \\
\hline income &,- 954 & ,245 &,- 286 & $\begin{array}{r}- \\
3,899\end{array}$ & ,000 \\
\hline
\end{tabular}

Sumber : Hasil perhitungan SPSS

Dengan memperhatikan tabel di atas, maka dapat diperoleh persamaan, yaitu :

$$
\begin{aligned}
\mathrm{Y}= & 14,154-0.111 \mathrm{X} 1+0,527 \mathrm{X} 2-0,954 \\
& \mathrm{X} 3+\mathrm{e}
\end{aligned}
$$

\section{PEMBAHASAN}

Pengaruh Locus of Control terhadap Financial Management Behavior pada instansi pemerintah Bappeda Provinsi Riau dan Bappeda Kota/Kabupaten

Hipotesis pertama dalam penelitian ini membuktikan bahwa kontrol diri (Locus of Control) tidak berpengaruh terhadap prilaku keuangan (Financial Management Behavior) pada instansi pemerintah Bappeda Provinsi
Riau dan Bappeda Kota/Kabupaten. Hal ini dapat dilihat dari hasil signifikan variabel (Locus of Control) yang bernilai 0,126. Sedangkan derajat signifikan yang digunakan adalah 0,05. Hal ini menunjukkan bahwa $\mathrm{H}_{1}$ ditolak, karena $0,126>0,005$.

Dengan demikian, dapat dikatakan apabila seseorang cenderung memiliki Internal Locus of Control yang buruk, maka Perilaku Keuangannya akan mengalami penurunan. Begitu juga sebaliknya, dan apabila seseorang mengalami kecenderungan menuju External Locus of Control yang buruk, maka Perilaku Keuangannya belum tentu mengalami penurunan.

\section{Pengaruh Financial Knowledge terhadap Financial Management Behavior pada instansi pemerintah Bappeda Provinsi Riau dan Bappeda Kota/Kabupaten}

Hipotesis kedua dalam penelitian membuktikan Pengetahuan Keuangan (Financial Knowledge) berpengaruh terhadap Perilaku Keuangan (Financial Management Behavior) pada instansi pemerintah Bappeda Provinsi Riau dan Bappeda Kota/Kabupaten. Hasil ini sama dengan keempat penelitian sebelumnya. Pada penelitian Perry dan Morris (2005) menyatakan, seseorang dengan Pengetahuan Keuangan yang baik akan memiliki perilaku keuangan yang lebih bertanggungjawab. Penelitian Grable dkk. (2009), nguyen thi (2015), serta Ida dan Chintia Yohana Dwinta (2010) menyatakan, terdapat pengaruh Financial Knowledge terhadap Financial Management Behavior.

Sehingga dapat disimpulkan apabila financial Knowledge seseorang itu baik maka akan berdampak baik pula pada financial management behavior, begitu juga sebaliknya. 
Pengaruh Income terhadap Financial Management Behavior pada instansi pemerintah Bappeda Provinsi Riau dan Bappeda Kota/Kabupaten

Hipotesis ketiga pada penelitian ini membuktikan bahwa Income berpengaruh terhadap Financial Management Behavior. Hasil ini sama halnya dengan 3 penelitian sebelumnya yaitu penelitian Perry (2005), oki (2015) dan nguyen thi (2015) yang menyatakan Income berpengaruh positif terhadap Financial Management Behavior. Adapun pada penelitian ini, didukung oleh responden telah bekerja dan memiliki pendapatan tetap.

Sehingga dapat disimpulkan bahwa apabila income seseorang itu meningkat maka akan berdampak baik pula terhadap Financial Management Behavior. Begitu juga sebaliknya. Misalnya, sebagian income yang diperoleh di tabung, dan dipergunakan secara efisien dan efektif di saat dibutuhkan.

\section{SIMPULAN}

Hasil penelitian menunjukkan bahwa secara statistik variabel Locus of Control, Financial Knowledge, Income secara simultan berpengaruh signifikan terhadap Financial Management Behavior $(\mathrm{p}<0,05)$ dengan persentase pengaruh locus of control sebesar $-11,1 \%$, Pengaruh financial knowledge sebesar $52,7 \%$ dan income sebesar $-95,4 \%$. Untuk hasil penelitian secara parsial menunjukkan variabel Locus of Control tidak berpengaruh terhadap Financial Management Behavior,sedangkan Financial Knowledge dan Income berpengaruh signifikan terhadap Financial Management Behavior

$$
\text { Disarankan kepada Instansi }
$$

Pemerintah Bappeda Provinsi Riau dan Bappeda Kota/Kabupaten untuk :1) Meningkatkan Locus of Control dengan menggunakan sistem reward and punishment kepada pegawai yang berprestasi atau berbuat kesalahan , 2) Meningkatkan Financial Knowledge pegawai dengan cara sering memberikan pelatihan dengan mendatangkan nara sumber yang kompeten 3) Menyusun pola pemberian Income berdasarkan kinerja pegawai

\section{DAFTAR RUJUKAN}

Aaker, David A. (2004). Brand Portfolio Strategy: Creating Relevance, Differentiation, Energy, Leverage and Clarity., Simon \& Schuster. New York.

Abu Ahmadi dan Widodo Supriyono. (2008). Psikologi Belajar. Rineka Cipta. Jakarta.

Amanda Stake. Religiosity, Locus of Control, and Superstitious Belief. UW-L Journal of Undergraduate Research VII (2004)

Anonimus. (2004). Undang-Undang Nomor 25 Tahun 2004 tentang Sistem Perencanaan Pembangunan Nasional

ANZ Bank , (2003). ANZ Survey of Financial Literacy In Australia.

Belkaoui, Ahmed Riahi (1993), Accounting Theory, Third Edition, Harcourt Brace Company, OrlandoFlorida.

Brigham F. Eugene dan Houston, Joel. (2010). Dasar-Dasar Manajemen Keuangan : Assetials Of Financial Management. Penerbit Salemba Empat. Jakarta.

Byrne, A. (2007). Employee saving and investment decisions in defined contribution pension plans: survey evidence from the U.K. Financial Services Review 16 (2007) 19-40 .

Case, Karl E, (2007). Prinsip-prinsip Ekonomi, Edisi Kedelapan, New Jersey : Pearson.

Deacon, R.E., \& Firebaugh, F.M. (1981). Family Resource Management 
Principles and Aplications. 470. Atlantic Avenue. Boston.

Nur Indriantoro, M.Sc., (2002). Metedologi Penelitian Bisnis. Yogyakarta : Edisi Pertama, Penerbit BPFE.

Duffy, K. G., \& Atwater, E. (2005). Psychology for living : Adjustment, Growth, and Behavior Today $(8$ ed.). New Jersey: Prentice Hall.

Ghozali, Imam. (2006), Aplikasi Analisis Multivariate dengan program SPSS, Cetakan Keempat, Badan Penerbit Universitas Diponegoro, Semarang.

Haris Munandar , (2007). Lanskap Ekonomi Indonesia, Kajian, dan Renungan Terhadap Masalah-Masalah Struktural, Transformasi Baru dan Prospek Perekonomian Indonesia, Kencana, Jakarta.

Hartono, Budi, (2010).Cerdas Keuangan! Kesadaran Keuangan untuk Hidup Lebih Sejahtera, [Online] Available: http://www.vbiznews.com/column/fi nancial/2010/09/27/ cerdas keuangan kesadaran keuangan untuk hidup lebih sejahtera.

Heck, Ramona (1984). The Determinants of Financial Management Behaviors among College Student : implications for Costumer Education, The Journal of Consumer Education, Vol. 2, 1984

Henry Faizal Noor, (2009). Investasi, Pengelolaan Keuangan Bisnis, dan Pengembangan Ekonomi Masyarakat, Jakarta.

Hilgert, M., \& Reichel, C. D. (2003). Drehem administrative documents from the reign of Amar-Suena. Chicago, Ill.: Oriental Institute of the University of Chicago.
Ida, dan Dwinta, Cinthia Yohana. (2010). Pengaruh Locus of Control, Financial Knowledge, Income terhadap Financial Management Behaviour. Jurnal Bisnis dan Akuntansi. Vol. 12, No. 3, pp. 131144.

Ikatan Akuntan Indonesia . (2007) . Standar Akuntansi Keuangan . Edisi 2007. Penerbit : Salemba Empat . Jakarta.

Kunarjo. (2002). Perencanaan dan Pengendalian Program Pembangunan. Jakarta

Lusardi, A. \& Mitchell, OS (2007). Financial literacy and retirement preparedness: Evidence and implications for financial education. Business Economics, 42(1), 35-43.

Lusardi, A \& Mitchell, O. S. (2007). Baby Boomer retirement security: The roles of planning, financial literacy, and housing wealth. Journal of Monetary Economics 54 (2007) 205-224.

Mankiw, N Gregory (2003), Pengantar Ekonomi, Edisi ke-2 Jilid 2 Erlangga. Jakarta.

Mauritius, (2007). Baquant,J. R Panray Beeharry dan B Gobin. " Ethanol Stove for Mauritius “.

Monks, dkk. (2004). Psikologi Perkembangan Pengantar dalam Berbagai Bagaiannya. Yogyakarta

Peraturan Pemerintah Nomor 8 Tahun 2008 tentang Tahapan, Tata Cara Penyusunan, Pengendalian, dan Evaluasi Pelaksanaan Rencana Pembangunan Daerah 
Pervin, L.A., Cervone, D., John, O.P. (2005). Personality: Theory and Research. Hoboken. NJ: Wiley.

Robbins, Stephen P. (2001). Perilaku Organisasi, Konsep, Kontroversi, Aplikasi, Alih Bahasa: Hadyana Pujaatmaka dan Benyamin Molan, Prenhallindo, Jakarta.

Rosplock, Kirby. (2010). Gender Matters: Men's and Women's Perceptions of Wealth are Mostly Aligned. Vol. 12 (4): 15-30. The Journal of Wealth Mangement.

Rotter J.B. (1966). Genaralized Expectancies for Internal Versus External Control of Reinforcement. Pshycologycal Monographs, 80 Whole No. 69.

Sekaran, U. 2003. Research Methods for Business : A Skill Building Approach 2 nd Edition, John Wiley and Son. New York.

Sofyan Syafri H. (2001). "Analisa Kritis Atas Laporan Keuangan". Raja Grafindo Persada. Jakarta.

Stendardi, Edward J. dan Judy F. Graham (2006), The Impact of Gender on The Personal Financial Planning Process.

Stice dan Skousen. (2009). Akuntansi Intermediate, Edisi Keenam Belas, Buku 1, Salemba Empat, Jakarta.

Sugiyono. (2006). Metode Penelitian Pendidikan. Alfabeta. Bandung.

Sugiyono. (2007). Metode Penelitian Pendidikan. Alfabeta. Bandung.

Sugiyono. (2009). Metode Penelitian Pendidikan. Alfabeta. Bandung.

Sugiyono. (2011). Metode Penelitian Pendidikan. Alfabeta. Bandung.
Tanuwijaya, (2009). Sistem Informasi: konsep, teknologi dan manajemen. Yogyakarta: Penerbit Graha Ilmu.

Widarjono, Agus, 2005. Ekonometrika Teori dan Aplikasinya, Edisi Pertama. Ekonisia Yogyakarta.

Worthington, Andrew C, (2006). Predicting Financial Literacy in Australia, Financial Services Review 15 pp59-79, Wollongong, Australia.

Yates, Dan, dan Chris Ward, (2011). Financial Literacy: Examining The Knowledge Transfer Of Personal Finance From High School To College To Adulthood, The Clute Institute, USA.

Yoga, Paulus, (2011). Kesadaran Masyarakat Mengatur Keuangan Bulanan Masih Rendah, [Online] http:

//www.infobanknews.com/2011. 